\title{
Due diligence driving the Success of Mergers and Acquisitions in Macedonia
}

\author{
Dushica Stevchevska-Srbinoska \\ University American College Skopje, Skopje, Macedonia \\ E-mail: dusica1@yahoo.com
}

Received: June 18, 2016 Accepted: July 09, 2016 Published: August 03, 2016

doi:10.5296/ijafr.v6i2.9618 URL: http://dx.doi.org/10.5296/ijafr.v6i2.9618

\begin{abstract}
The act of due diligence is of vital importance when considering the possibility to enter the Macedonian market through merger and/or acquisition transactions. In this paper, I discuss that due diligence helps reduce potential risks or even results with curtailing the transaction as most of the Letters of intent never come to life. Many Macedonian entities, both public and private, operate in an environment considerably different to the European Union economies, a fact that inspires many questions with potential investors, especially in those who come from the European Union. If proper preparation takes place, and the expectations and processes are duly taken into account, successful merger and/or acquisition can be conducted in the Republic of Macedonia in spite of facing numerous difficulties. Finally, I discuss that several suggestions/factors can maximize the chances of success, demonstrated with the example of due diligence process set-up prior to the one. Vip merger that marked the Macedonian communications industry in 2015.
\end{abstract}

Keywords: Due diligence, Merger and acquisition, Macedonian market 


\section{Macrothink \\ International Journal of Accounting and Financial Reporting \\ ISSN 2162-3082 \\ 2016, Vol. 6, No. 2}

\section{Introduction}

When considering the possibility to enter the Macedonian market through merger and/or acquisition transactions, due diligence helps reduce potential risks. Many Macedonian entities, both public and private, operate in an environment considerably different to the European Union economies, a fact that inspires many questions with potential investors, especially in those who come from the European Union. If proper preparation takes place, and the expectations and processes are duly taken into account, successful merger and/or acquisition can be conducted in the Republic of Macedonia in spite of facing numerous difficulties.

\section{Setting up the Due diligence process in the Republic of Macedonia}

The most common problem rests with unresolved land tenure rights and land under State ownership. Accordingly, the due diligence process reveals unsettled transfers of land use rights which entails major financial implications because the State may ask for title settlement before or after the completion of the desired M\&A transaction.

Another problem arises from unsettled tax liabilities. Many enterprise have separate accounting for the purpose of tax evasion, Value added tax in particular, given its intake in total taxes payable. Income tax may be of lesser value because of various tax reliefs, especially connected to entities operating in the so-called free economic zones.

If proper preparation takes place, and the expectations and processes are duly taken into account, successful merger and/or acquisition can be conducted in the Republic of Macedonia in spite of facing numerous difficulties, which is the focus of this paper. Several suggestions/factors can maximize the chances of success (Ulrich and Kummer, 2007).

\section{- Engaging advisors in a timely fashion}

Engaging advisors prior to submitting the Letter of intent enables higher transparency of the target entity which enables faster execution of the Letter of intent. It is of uttermost importance not to introduce the counselors as inspectors to avoid negative resonance among the Macedonians involved in the process because the term inspectors is usually associated with inspection and control-related activities with negative or even daunting undertone. The initial stage should be defined as a preliminary process for data collection purposes that will ease the completion of the potential transaction.

\section{- Understanding the due diligence process differences between the EU countries and the Republic of Macedonia}

Initiating the due diligence process with solid expectations is of essential meaning for potential EU investors. The financial statements, financial infrastructure and the business processes are on a lower ladder than their EU counterparts, which necessitates higher attention towards several potentially risky operation segments and prolongs the due diligence duration. Part of the due diligence differences in comparison to the EU practices are presented in the table below. 
Table 1. Due diligence process - European Union vs. the Republic of Macedonia

\begin{tabular}{|c|c|c|}
\hline \multicolumn{3}{|c|}{ Due diligence process - European Union vs. Republic of Macedonia } \\
\hline & European Union & Republic of Macedonia \\
\hline 1. Financial data transparency & High & Low \\
\hline 2. Due diligence duration & $1-2$ months & $1-3+$ months \\
\hline $\begin{array}{l}\text { 3. Duration of the preparation } \\
\text { process in the target entity } \\
\text { prior to starting due } \\
\text { diligence }\end{array}$ & Brief & $\begin{array}{l}\text { May be prolonged } \\
\text { considerably }\end{array}$ \\
\hline $\begin{array}{l}\text { 4. Basis for preparation of the } \\
\text { financial statements }\end{array}$ & IFRS or US GAAP & $\begin{array}{l}\text { IFRS or local accounting } \\
\text { standards applicable for } \\
\text { tax filing submission }\end{array}$ \\
\hline 5. Revised financial statements & IAS & $\begin{array}{l}\text { IAS, disputable quality at } \\
\text { times }\end{array}$ \\
\hline $\begin{array}{l}\text { 6. Transaction with related } \\
\text { parties }\end{array}$ & $\begin{array}{l}\text { Of different value, } \\
\text { compulsory } \\
\text { disclosure }\end{array}$ & $\begin{array}{l}\text { Of high value, often } \\
\text { inadequate/insufficient } \\
\text { disclosure }\end{array}$ \\
\hline 7. Contingent liabilities & $\begin{array}{l}\text { Transparent } \\
\text { disclosure }\end{array}$ & $\begin{array}{l}\text { Are of high risk, } \\
\text { infrequent disclosure }\end{array}$ \\
\hline $\begin{array}{l}\text { 8. Computerized accounting } \\
\text { systems }\end{array}$ & Yes & $\begin{array}{l}\text { Automation in progress, } \\
\text { manual processes still } \\
\text { present }\end{array}$ \\
\hline $\begin{array}{l}\text { 9. Proper products/services } \\
\text { warranties }\end{array}$ & Mostly yes & Mostly no \\
\hline $\begin{array}{l}\text { 10. Realization of claims } \\
\text { (financial compensation) }\end{array}$ & $\begin{array}{l}\text { Yes - adequate } \\
\text { court support }\end{array}$ & $\begin{array}{l}\text { Imperfect, sluggish court } \\
\text { execution }\end{array}$ \\
\hline
\end{tabular}

Apart from the general accounting process deficiencies, the local accounting standards are different than the standard accounting practices adopted by IFRS. Such an example is the 


\section{Mll Macrothink}

International Journal of Accounting and Financial Reporting

ISSN 2162-3082

2016, Vol. 6, No. 2

allowance for doubtful accounts which does not represent accurate evaluation of the quality of accounts receivable. Namely, the allowance is acknowledged for tax purposes only if the bad debt reserve is supported by enforceable court judgment for bad debt, a process which is far from perfect due to the inefficient court system. Therefore, the accounting practices due diligence should focus on early identification and evaluation of the income and working capital adequacy.

\section{- Dealing with internal expectations}

In the Republic of Macedonia, enforcing the transaction often becomes goal by itself and can become misleading given the initial targets and expectations. The internal expectations should be properly handled, which is a great challenge by itself. Hence, initiating early preparation is of vital meaning where no investment should be executed without prior analysis of potential deficiencies which may be detected upon due diligence.

\section{- Patience}

The presence in any market necessitates certain degree of patience. This is also valid for the Republic of Macedonia where the investor's motives are often put to test and only a small number of Letters of intent are completed with implementation of the desired transaction. There are three key reasons for failing the transactions on the Macedonian market evaluation of the revenue quality, lack of transparency in due diligence, and timeframe of the process from the expression of interest until signing of the transaction papers which may often last longer than one or two years.

\section{Stages of the Due diligence process in the Republic of Macedonia}

It is recommendable to conduct the due diligence in several stages. Proper tasks should be defined prior to signing the Letter of intent. These tasks are normally segmented in the following fashion.

Table 2. Collection of data prior to signing the Letter of intent

\section{Collection of data prior to signing the Letter of intent}

\begin{tabular}{|c|l|}
\hline Potential tasks & Goals \\
\hline 1. Scanning historical audit reports & $\begin{array}{l}\text { Understand the core operation drivers, } \\
\text { revenue quality, working capital quality, etc. }\end{array}$ \\
\hline $\begin{array}{l}\text { 2. Evaluation of the main accounting } \\
\text { policies }\end{array}$ & $\begin{array}{l}\text { Identify the potentially risky/sensitive areas } \\
\text { that should be thoroughly inspected, } \\
\text { evaluated and structured upon due diligence. }\end{array}$ \\
\hline 3. Analyzing the complete picture & $\begin{array}{l}\text { Evaluate the financial data integrity and } \\
\text { quality. }\end{array}$ \\
\hline
\end{tabular}


4. Evaluation of the financial and accounting environment

5. Revision of the internal management reports

6. Understanding the operations
Highlight the deficiencies of the accounting software used, prepare expectations regarding the vital financial data that will be used for further analyses.

Prepare information that will be used as basis for due diligence.

Analysis of the valuation impact and identification of areas that will be subject to detailed review.

Securing sufficient information for the purpose of better analysis. information before initiating the due diligence process

Upon signing the Letter of intent, it is highly recommendable to conduct the analysis in two stages. Certainly, virtual data rooms on both sides support the purchasing entity's due diligence checklist demands and data organization, easing a smoother transaction.

Table 3. Due diligence procedures upon signing the Letter of intent

\section{Due diligence procedures upon signing the Letter of intent}

\begin{tabular}{|c|l|}
\hline Potential tasks & Goals \\
\hline First stage & $\begin{array}{l}\text { Identification of risk areas that need to be } \\
\text { attended }\end{array}$ \\
\hline 1. Revising auditor notes & $\begin{array}{l}\text { Validate the book value of the } \\
\text { assets/liabilities and evaluate the forthcoming } \\
\text { revenue impact. }\end{array}$ \\
\hline $\begin{array}{l}\text { 2. Getting familiar with the assets andilies of the entity } \\
\text { liabilatements }\end{array}$ & $\begin{array}{l}\text { Understand seasonality, assess the revenue } \\
\text { quality. }\end{array}$ \\
\hline $\begin{array}{l}\text { 3. Analyzing financials stactuations pro-forma } \\
\text { 4. Addressing potential } \\
\text { changes }\end{array}$ & $\begin{array}{l}\text { Assess the historical profitability of the target } \\
\text { entity. }\end{array}$ \\
\hline 5. Assessing additional areas & Evaluate the hidden expenses of the target \\
\hline
\end{tabular}




\begin{tabular}{|l|l|}
\hline & entity. \\
\hline 6. Identifying contingent liabilities & $\begin{array}{l}\text { Assess the impact on value and identify areas } \\
\text { for due diligence. }\end{array}$ \\
\hline
\end{tabular}

The Firsts stage findings often indicate the need to reinvestigate the decision to implement the merger/acquisition transaction - the value of the deal drops leading to different expectations from the transaction driven by the new risk evaluation. Nonetheless, should the assessment continue, it is recommendable to proceed with a more thorough assessment of the following areas (i.e. Stage two).

Table 4. Standard due diligence procedures after signing the Letter of intent

\section{Standard due diligence procedures after signing the Letter of intent}

\begin{tabular}{|c|c|}
\hline Potential tasks & Goals \\
\hline \multicolumn{2}{|l|}{ Second stage } \\
\hline $\begin{array}{l}\text { 1. Evaluating the profitability per } \\
\text { product/segment/geographic location }\end{array}$ & $\begin{array}{l}\text { Detailed operations assessment, evaluation } \\
\text { of revenue quality. }\end{array}$ \\
\hline $\begin{array}{l}\text { 2. Analyzing price and quantity } \\
\text { correlation }\end{array}$ & $\begin{array}{l}\text { Detailed operations assessment, evaluation } \\
\text { of revenue quality. }\end{array}$ \\
\hline $\begin{array}{l}\text { 3. Identifying core cost drivers and cost } \\
\text { variations }\end{array}$ & $\begin{array}{l}\text { Detailed operations assessment, evaluation } \\
\text { of revenue quality. }\end{array}$ \\
\hline $\begin{array}{l}\text { 4. Reassessing historical capital } \\
\text { investments }\end{array}$ & Assessment of the valuation impact. \\
\hline $\begin{array}{l}\text { 5. Analyzing the sensitivity of working } \\
\text { capital and seasonality patterns }\end{array}$ & $\begin{array}{l}\text { Assessment of the valuation; assessment of } \\
\text { the financials needs of the target entity. }\end{array}$ \\
\hline 6. Analyzing budget deviations & $\begin{array}{l}\text { Assessment of the forecasted budget and } \\
\text { profitability of the target entity. }\end{array}$ \\
\hline 7. Evaluating the human resources & Assessment of the valuation impact. \\
\hline 8. Quantifying the EBITDA & Assessment of the valuation impact. \\
\hline 9. Finalizing the due diligence report & $\begin{array}{l}\text { Summarizing the key findings and } \\
\text { observations, potential problems, if any, for }\end{array}$ \\
\hline
\end{tabular}




\begin{tabular}{|l|l|}
\hline & $\begin{array}{l}\text { the purpose of facilitating the } \\
\text { acquisition/merger decision. }\end{array}$ \\
\hline $\begin{array}{l}\text { 10. Analyzing warranty } \\
\text { liabilities/receivables according to the } \\
\text { purchase agreements from financial } \\
\text { point of view }\end{array}$ & $\begin{array}{l}\text { Support the target entity for the purpose of } \\
\text { minimizing the investment risk. }\end{array}$ \\
\hline
\end{tabular}

Foreign entities willing to invest in the Republic of Macedonia are faced with language barriers, cultural differences, and unfamiliarity with the local business practices. This is why it is of utmost importance for foreign investors to apply a system of well-defined steps upon investigating the investment opportunities, taking into account the internal opportunity expenses as well as the expenses for engaging external advisors. The Republic of Macedonia is undergoing an active economic transition towards establishing a free market economy which is why the business environment is exposed to continuous changes. In this respect, the accounting milieu is undergoing fast development, and not all accountants are adequately trained. Understanding the core cultural differences, the potential difficulties, and the success factors is basis for conducting the due diligence process and for determining which areas need to be thoroughly examined while benefiting from the involvement of professional external advisors.

\section{Case study: Due diligence of the Macedonian communications provider ONE prior to one. Vip merger}

This paper will illustrate the importance of the acumen reached upon conducting due diligence in ONE prior to the merger with Vip operator dooel Skopje into one.Vip doo that took place in Q4 2015 (Telekom Austria Group Newsroom, 2015). The merger's core intention was to generate a new company with larger investment capacity and greater competiveness. One.Vip was expected to be beneficial for residential and business customers, while also fostering competition in all affected sectors on products, quality, and prices.

The Macedonian Commission for Protection of Competition approved the merger of Telekom Austria Group's Macedonian subsidiary Vip Operator (established in 2007) with Telekom Slovenije's subsidiary ONE (established in 2007), with 55\% vested in Telekom Austria Group with sole control over the new company. The contract foresees call and put options for the exit of Telekom Slovenije Group within three years following the merger. MVNO access to interested operators was a basic condition to the merger approval in order to ensure competitiveness of products and prices should new market players embark on virtual operations.

Prior to merging, ONE occupied the third position in the mobile communications market of the Republic of Macedonia, with SIM market share of more than 26\% at the end of Q3 2015 and customer base of circa 600k subscribers. In 2014, ONE achieved total revenues and EBITDA of approximately $75.7 \mathrm{mn}$ EUR and $10.6 \mathrm{mn}$ EUR respectively.

In the common practice of Telekom Austria Group, legal and financial due diligence are 
outsourced to external experts where a reputed local law firm was engaged in the assessment of legal documents, while an internationally acknowledged audit firm performed the financial assessment. Given the sensitivity upon conducting business appraisals, operational Due Diligence Teams (especially technical and marketing teams) are staffed internally in order to benefit from the expertise of local experts from various departments (marketing, sales, controlling, customer service, technical, regulatory, HR and legal). Team members report to the respective Stream Leader, they report to the Project Manager. The Project Manager has to make sure that individual Streams are aligned.

Graph 1.Document Flow in one. Vip Merger Project (Telekom Austria Group, 2016)

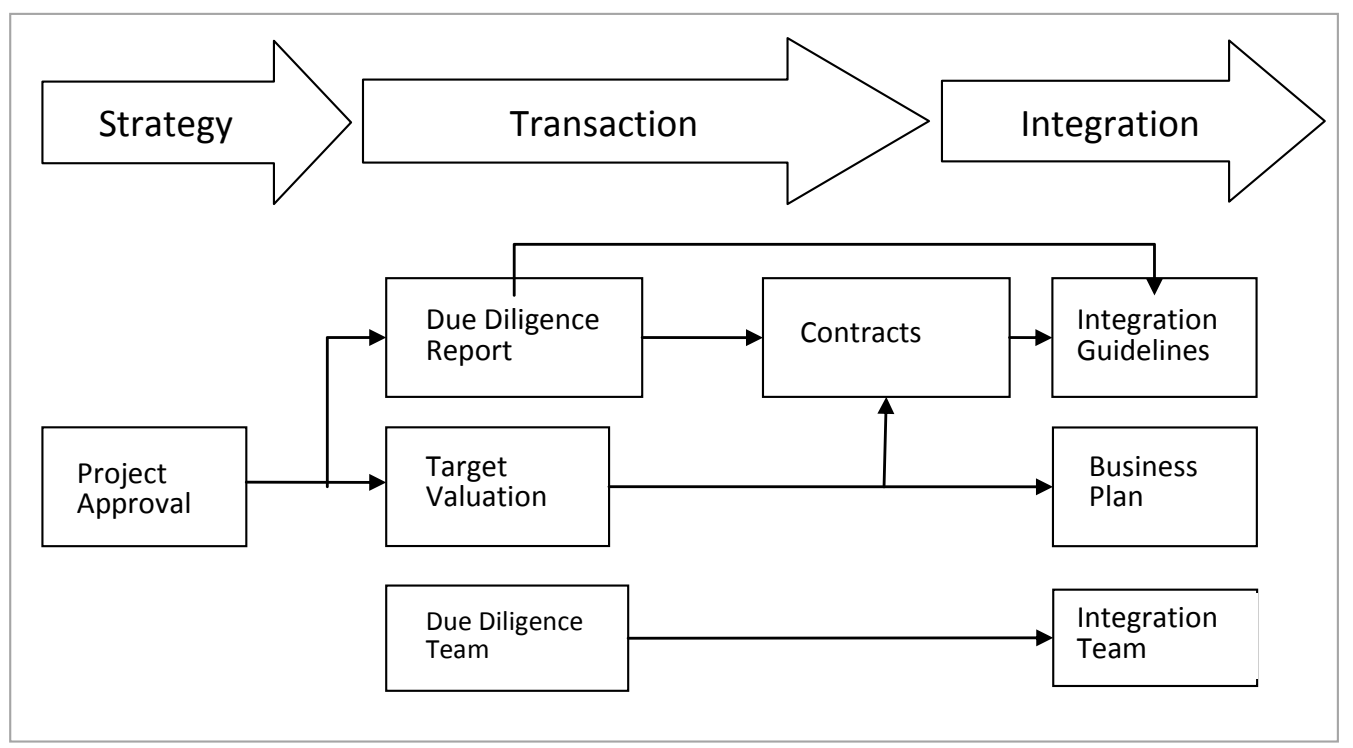

Timing-wise, the due diligence project of ONE was stretched from the initially planned 4-6 weeks in the Data Room to more than 2 months due to processing of large quantity of questions and lack of resources needed to process data in ONE's Data Room. Once the Data Room step was completed, it took another week to run the due diligence report and complete the valuation phase.

The due diligence of ONE provided insight into financial and operational performance of the target entity. This paper will focus on the process organization and data collection phase necessary to avoid post-merger integration concerns. Prior to one.Vip merger transaction, several areas were prudently examined (Telekom Austria Group, 2014):

\subsection{Accounting due diligence}

The financial examination of ONE gathered details on operations and accounting approach behind financials. Core aspects subject to scrutiny were:

- Accounting policies and deferral practices,

- Capital and debt structure,

- Contingent assets and liabilities, especially if not properly disclosed, 


\section{Macrothink \\ International Journal of Accounting and Financial Reporting \\ ISSN 2162-3082 2016, Vol. 6, No. 2}

- Employee and tax liabilities,

- Outstanding debt and reason for delayed or non-payment,

- Revision of all active Contracts especially the contractual conditions, prices and timelines - possibility to renegotiate the terms to generate savings (horizontal merger synergies due to overlapping of operational areas)

- Warranty liabilities and outstanding Bank guarantees,

- Existing internal control mechanisms,

- Historical internal auditor reports and notes,

- Annual stock taking reports and findings,

The accounting assessment had to anticipate and neutralize the financial risks from operations, thus enabling smoother post-merger integration. KPMG, the Vip operator auditor of that time, were engaged to perform the financial review. The auditor combined their knowledge of Telekom Austria Group and their wide international know-how, to complete the engagement.

\subsection{Legal due diligence}

The M\&A team of Telekom Austria Group also focused on legal due diligence of ONE in order to ensure that no legal violations exist or that the violation amounts have been duly disclosed. The review encompassed access to:

- The Articles of association of ONE,

- License agreement with the Macedonian Agency for electronic communications,

- Register of ONE's statutory liabilities (status of dues like license and spectrum fees, profit and value added taxes, interconnection amount due),

- Intellectual property rights and infringements,

- Contracts behind capital investments,

- Assessment of key contracts (with network service providers, TV content services, collection companies, lessors for base station sites, sales channel partners and master dealers, roaming agreements, VAS service vendors, etc.),

- Status review of all legal cases filed by and against ONE,

- Minutes of Management and Supervisory Board meetings of the last five years.

Given the quantity of legal documents and contracts that had to be reviewed and properly evaluated, a renowned Macedonian legal firm (given the local law specifics) was engaged in the process. The legal revision helped value ONE's legal build and reveal problems before committing to merger. 


\section{Macrothink \\ International Journal of Accounting and Financial Reporting \\ ISSN 2162-3082 \\ 2016, Vol. 6, No. 2}

\subsection{Operations due diligence}

The operations assessment had to ensure maximized financial worth of the new entity. This stage encompassed the business, technical, and HR appraisals.

\subsubsection{Business and Marketing appraisal}

As the targeted merger was of horizontal character, the examination focused on several operational performance indicators:

- ARPU/L per subscription and customer segment,

- Revenues per unit charged i.e. airtime revenue,

- Retail and wholesale revenue structure,

- Current market share vs projected market share(s) in both mobile and fixed operation segments,

- Customer base quality,

- Appraisal of brand perception and marketing strategy,

- Customer care approach,

- Sales channel ability to promote the products of the new entity to the detriment of competitors,

- Hard and soft synergies expected in the transaction aftermath,

- Potential emergence of new competitors in the Macedonian communications market,

- Strategic positioning to establish and preserve market leadership.

This aim is reinforced with the on-going hard and soft synergies tracking in the first two years following the merger event - cost reduction across operational segments being the hard synergies, followed by soft synergies through ARPU elevation, customer base upgrade via cross-selling, and higher RGU to subscriber ratio.

\subsubsection{Technology appraisal}

The technical review provided information on the quality of systems across all operational domains and the possibility for system integration between Vip operator and ONE:

- Network coverage and network assets quality,

- Maintenance and/or renovation stage of network assets,

- Potential incompatibility of Vip operator and ONE network assets with the target architecture and quantification of expected write offs,

- Billing system interface to the target financial system of one.Vip,

- Purchasing procedures and purchase order approval process, 


\section{Macrothink}

International Journal of Accounting and Financial Reporting

ISSN 2162-3082 2016, Vol. 6, No. 2

- Database behind the customer care system, customer ticket/complaint resolution time and ability to support customers throughout their lifespan.

The technological assessment took the appraisal one step closer to system integration in the new entity.

\subsubsection{Human Resource appraisal}

With human resources being vital for the future performance of one.Vip, the review looked into:

- Number of employees in total and per department,

- Number of outsourced employees,

- Employee ranking and salary range in comparison to industry,

- Content of Golden Parachute contracts with ONE management to be transferred to one. Vip's books.

This information helped determine if ONE's staff size exceeded requirements. The due diligence data helped in valuing the target entity and revealing problem areas before signing the transaction, such as stating in public that workforce reduction is to be expected in the middle term.

\subsection{Due diligence Output: Completion of Transaction Phase}

The main due diligence output of is the Due Diligence Report where all the findings, potentials and integration topics are presented. As demonstrated with the one.Vip merger transaction, this Report serves as a basis for:

- The decision to buy or not to buy (Board Presentation)

- The valuation of the asset (Valuation Model including Synergies)

- The ongoing negotiations with the target (Contracts)

- The integration planning (Integration Handbook)

The graph below presents the position of the Due diligence Report step in the merger and acquisition process. 
Graph 2. One.Vip Merger Project Management, with emphasis on Due Diligence Process, Transaction Phase (Telekom Austria Group, M\&A Process DD Team Briefing, 2016)

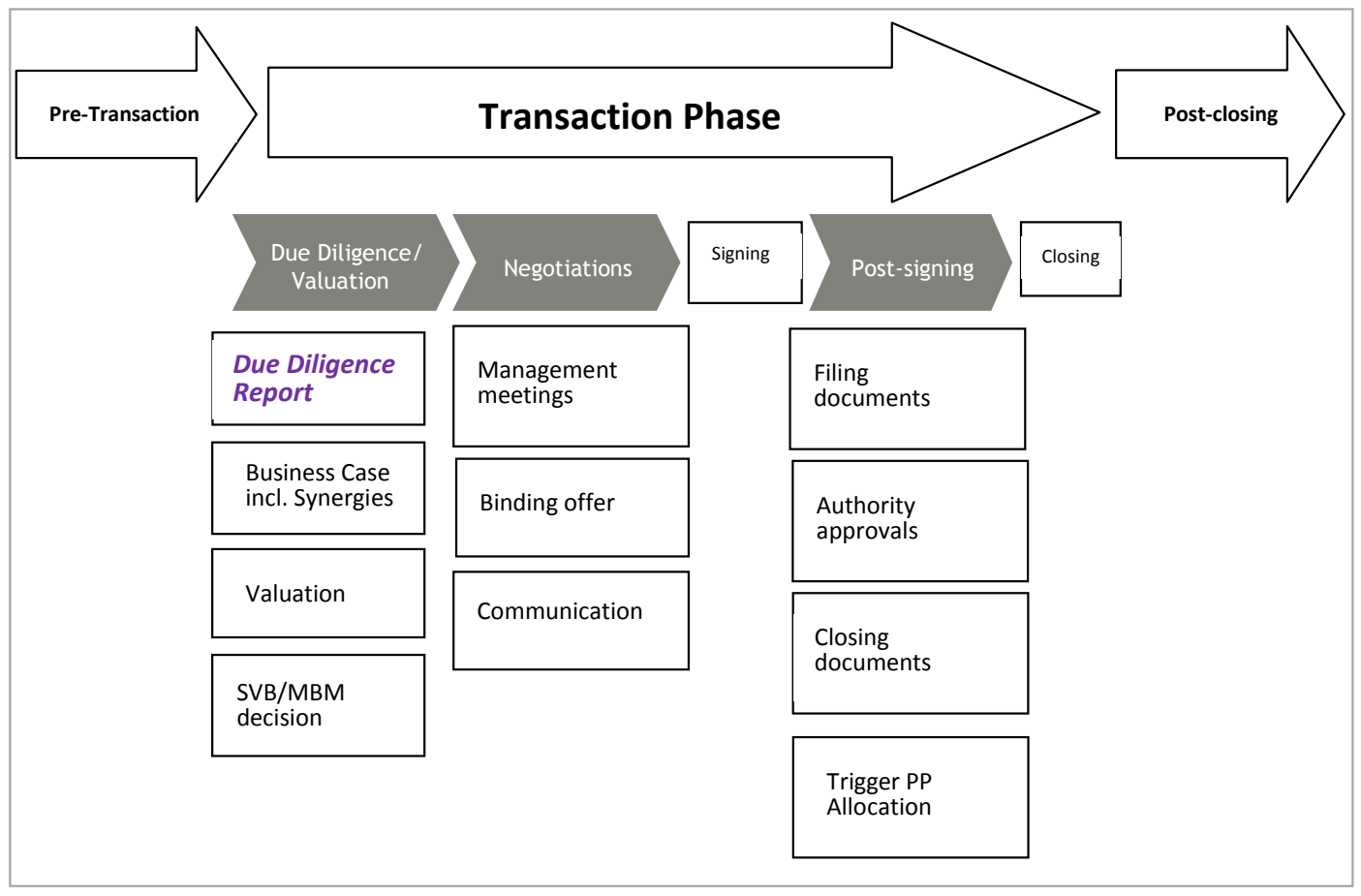

As demonstrated with the ONE due diligence, the Due Diligence Report takes into account that some topics are transferred to the seller, some are absorbed by the buyer, and some become part of the Valuation. Namely, topics presented as contingent liabilities normally remain risk for the seller within the negotiated M\&A Contract timeframe, such as use of enduser software licenses by more than the nominated employees. Secondly, the risks that come in the form of synergies are absorbed by the buyer: Telekom Austria Group absorbed in the Business Plan the expected EBITDA post-merger benefits in the form of potential cost cutting, marketing and sales savings, lower subsidy expenses, and renegotiated supplier contracts. Finally, the third type of risks is absorbed in the Valuation model and is used to put the purchase price down, such as asset-related risks prior to one.Vip merger with end of life equipment that needs to be refurbished or replaced in the near future in order to maintain operations on the Macedonian market.

The Due diligence Report, accompanied by Business Case calculation including synergies (preliminary Business plan of the future entity) and Valuation of ONE operations, was followed by a joint Supervisory and Management board meeting where decision to invest was made. Should the outcome be acceptable for all parties involved like in the one.Vip case, Negotiations Stage and Contract signing wrap up the agenda of the Transaction Phase.

\section{Conclusion.}

On the 10-year road to EU accession, the Republic of Macedonia embraced EU's telecommunication regulations, leaning towards the establishment of a liberalized market supervised by an independent body, the Macedonian Agency for electronic communications. 


\section{N Macrothink}

International Journal of Accounting and Financial Reporting ISSN 2162-3082 2016, Vol. 6, No. 2

The new framework spurred influx of capital investments in both, fixed and mobile communications networks, followed by multiple transactions of mergers and acquisitions. The M\&A wave in the industry reduced the number of mobile carriers from four in 2014 to two by the end of 2015. In parallel, intense consolidation is reducing the number of fixed operators, enabling future capital focus on innovation and technological benefits for customers. Following the 2015 merger transaction, one.Vip certainly demonstrates this focus on innovation with the intense post-merger $4 \mathrm{G}$ and cable network rollout along with development of rich convergent portfolio for the Macedonian subscribers.

Certainly, further ownership structure rearrangements in the existing market communication licenses along with entry of new players will continue. Hence, communications industry continuous restructuring will help keep up the pace with novelties in the sector where revenue and cost efficiencies cannot be achieved without solid set-up of due diligence prior to any M\&A transaction event. The due diligence of ONE provided insight into financial and operational performance of the target entity where process organization and data collection phase proved to be necessary to avoid post-merger integration concerns. But, this due diligence depicted some of the local market specifics that should be improved to approach the European Union practices, given the prolonged due diligence duration, with more than 2 months spent only in the ONE data room, incomplete disclosure of contingent liabilities, and Macedonian judicial system deficiencies resulting with slow realization of claims in ONE's case as across all local industries.

\section{Acknowledgement}

The research is supported by UACS Skopje.

\section{References}

Telekom Austria Group Newsroom, "Macedonian Competition Authority approves Merger of Vip Operator with ONE." [Online] Available:

http://www.telekomaustria.com/en/newsroom/2015-7-8-macedonian-competition-authorityapproves-merger-of-vip-operator-with-one.1 (July 8, 2015)

David Schweiger, M\&A Integration : A Framework for Executives and Managers, McGrawHill Companies Inc. 2002, New York

Galpin, Timothy $\mathbf{J}$ and Herndon, Mark. The complete guide to mergers and acquisitions: process tools to support M\&A integration at every level. San Francisco: Jossey-Bass Publishers; 1999.

Patrick A. Gaughan, "Mergers, Acquisitions, and Corporate Restructurings", second edition, New York: John Wiley \& Sons, 1999.

Paul A.Pautler, "Evidence on Mergers and Acquisitions", Federal Trade Commission: Working paper, 25 September 2001. 


\section{Macrothink}

International Journal of Accounting and Financial Reporting

ISSN 2162-3082

Philippe Haspeslagh and David Jemison, "Managing Acquisitions: Creating Value Through Corporate Renewal", New York: Free Press, 1991.

Picot, Gerhard. Handbook of international mergers and acquisitions: preparation, implementation, and integration. New York: Palgrave/Macmillan, 2002.

Ulrich Steger and Christopher Kummer, July 2007, "Why Merger and Acquisition (M\&A)Waves Reoccur - The Vicious Circle from Pressure to Failure", Chapters 3 and 4.

Telekom Austria Group, M\&A department, internal documents, April 2016.

Telekom Austria Group, M\&A department, “DD_Questionnaire”, May 2014.

Telekom Austria Group, M\&A department, internal documents, "MA Process DD Team Briefing", April 2016.

\section{Copyright Disclaimer}

Copyright for this article is retained by the author(s), with first publication rights granted to the journal.

This is an open-access article distributed under the terms and conditions of the Creative Commons Attribution license (http://creativecommons.org/licenses/by/3.0/). 